\title{
Infrared and Chemical Characterization of Natural Amethysts and Prasiolites Colored by Irradiation
}

\author{
Fernando Soares Lameiras ${ }^{\mathrm{a}}$, Eduardo Henrique Martins Nunes ${ }^{\mathrm{b}}$, Wander Luiz Vasconcelos ${ }^{\mathrm{c}}$ \\ ${ }^{\mathrm{a} C e n t r o ~ d e ~ D e s e n v o l v i m e n t o ~ d a ~ T e c n o l o g i a ~ N u c l e a r ~-~ C D T N ~(N u c l e a r ~ M a t e r i a l s), ~}$ \\ 31270-901 Belo Horizonte - MG, Brazil \\ ${ }^{\mathrm{b}}$ Lamil Lage Minérios Ltda. (Development), 35660-970 Pará de Minas - MG, Brazil \\ 'Departamento de Engenharia Metalúrgica e de Materais, \\ Universidade Federal de Minas Gerais, \\ 30160-030 Belo Horizonte - MG, Brazil
}

Received: December 23, 2008; Revised: May 8, 2009

\begin{abstract}
The infrared bands of amethyst and prasiolite samples from different origins were correlated to the trace elements contents. Amethysts have an iron content greater than $20 \mathrm{ppm}$ and a low content of sodium and potassium. Prasiolites have an aluminum content greater than $120 \mathrm{ppm}$ and a higher overall trace elements content, which accounts for a strong absorption between 3200 and $3600 \mathrm{~cm}^{-1}$. Colorless samples of quartz that become amethysts and prasiolites after irradiation have infrared spectra at room temperature with a broad band at $3441 \mathrm{~cm}^{-1}$ and a sharp band at $3595 \mathrm{~cm}^{-1}$. The broad band splits in several bands at low temperatures that are related to $\mathrm{Al}_{\mathrm{Si}}$ and $\mathrm{Fe}_{\mathrm{Si}}$. The color of amethysts and prasiolites are assigned to $\left[\mathrm{Al}_{\mathrm{Si}} \mathrm{O}_{4} / \mathrm{h}^{+}\right]^{0}$ and $\left[\mathrm{Fe}_{\mathrm{Si}} \mathrm{O}_{4} / \mathrm{h}^{+}\right]^{0}$ centers formed by the exposure to ionizing irradiation and to the influence of lattice distortions due to the content of iron as a substitute for silicon and a high content of trace elements of large ionic radius like potassium.
\end{abstract}

Keywords: amethyst, prasiolite, infrared spectrum, irradiation, trace elements

\section{Introduction}

Amethyst is a violet variety and prasiolite is a green variety of natural quartz. They are appreciated as gemstones. These colors can be bleached by heating or exposure to intense ultraviolet radiation. The heating of amethyst and prasiolite may also produce yellow colors. Some occurrences of natural colorless quartz may be transformed in amethyst or prasiolite by exposure to high energy ionizing radiation (e. g., gamma rays, X-rays, or electron beam). They are routinely exposed to ionizing radiation to produce amethyst and prasiolite for jewelry. This is a well-established economic activity in the states of Minas Gerais and Rio Grande do Sul in Brazil. The understanding of the color formation mechanism is necessary for the control of the extraction and irradiation of natural colorless quartz to produce amethyst and prasiolite.

The causes of color of amethyst have been investigated since $1899^{1}$. The violet color have been explained in association with trace elements in small inclusions in the quartz matrix, or as substitutes for silicon, or in interstitial positions in the quartz crystal lattice, and to the exposure of quartz to natural ionizing irradiation ${ }^{2,3,4,5}$. Synthetic amethyst and prasiolite samples were grown in autoclaves in aqueous medium with alkaline and iron ions ${ }^{6}$. Aluminum and iron are the trace elements usually assigned as substitutes for silicon in the quartz lattice. Since $\mathrm{Al}^{3+}$ or $\mathrm{Fe}^{3+}$ replace $\mathrm{Si}^{4+}$ in the center of a $\mathrm{SiO}_{4}$ tetrahedron (designated as $\mathrm{Al}_{\mathrm{Si}}{ }^{3+}$ or $\mathrm{Fe}_{\mathrm{Si}}{ }^{3+}$ ), the charge deficiency requires an interstitial positive monovalent ion in the vicinity to neutralize the electric charge. $\mathrm{H}^{+}, \mathrm{Li}^{+}$, and $\mathrm{Na}^{+}$are usually considered as charge compensators ${ }^{7-14}$. Interstitial $\mathrm{Fe}^{3+}$ was also proposed as charge compensator for $\mathrm{Fe}_{\mathrm{Si}}{ }^{3+[3]}$. The formation of $\mathrm{Fe}_{2} \mathrm{O}_{3}$ microinclusions and the presence of oxygen vacancies were also used to explain the formation of yellow colors after the heating of some amethysts ${ }^{15}$. These $\left[\mathrm{Al}_{\mathrm{Si}} \mathrm{O}_{4} / \mathrm{M}^{+}\right]^{0}$ or $\left[\mathrm{Fe}_{\mathrm{Si}} \mathrm{O}_{4} / \mathrm{M}^{+}\right]^{0}$ centers $\left(\mathrm{M}^{+}\right.$is the charge compensator) are supposed to have a relation to the color formation in quartz by exposure to irradiation and heat. The relation of $\left[\mathrm{Al}_{\mathrm{Si}} \mathrm{O}_{4} / \mathrm{h}^{+}\right]^{0}$ center to smoky quartz is well accepted in the literature $\left(\mathrm{h}^{+}\right.$is an electron hole). This center is also noted as $\left[\mathrm{AlO}_{4}\right]^{0}$.

The infrared spectrum of natural colorless quartz between 2400 and $4000 \mathrm{~cm}^{-1}$ is correlated to the potential of color development by irradiation and heating ${ }^{16,17}$. Bands related to hydroxyl between 3200 and $3600 \mathrm{~cm}^{-1}$ are influenced by the trace elements. The bands at room temperature at 3381,3433 , and $3483 \mathrm{~cm}^{-1}$ are respectively related to $\mathrm{Al}_{\mathrm{Si}}-\mathrm{OH}, \mathrm{Al}_{\mathrm{Si}}-\mathrm{OH} / \mathrm{Na}^{+}$, and $\mathrm{Al}_{\mathrm{Si}}-\mathrm{OH} / \mathrm{Li}^{+} 8,11,18$. Colorless samples that produce amethyst and prasiolite after irradiation show at room temperature a broad band at $3441 \mathrm{~cm}^{-1}$ and a sharp band at $3585 \mathrm{~cm}^{-1}$. The nature of these bands is not yet resolved.

Prasiolite usually occurs in nature in geodes, like amethyst. It is common to find both prasiolite and amethyst in the same place. The irradiation of colorless quartz may also produce prasiolite and amethyst. Due to these similarities, prasiolite is occasionally designated as "green amethyst". The infrared spectra also support the similarities between these quartz.

This paper presents comparative results of the characterization of amethyst and prasiolite in order to establish the differences between these varieties of quartz and to discuss the nature of the infrared bands between 3200 and $3600 \mathrm{~cm}^{-1}$.

\section{Experimental}

Samples of natural amethyst and prasiolite from different occurrences were collected (see Table 1). The trace elements contents in the samples were measured by inductively coupled plasma atomic 


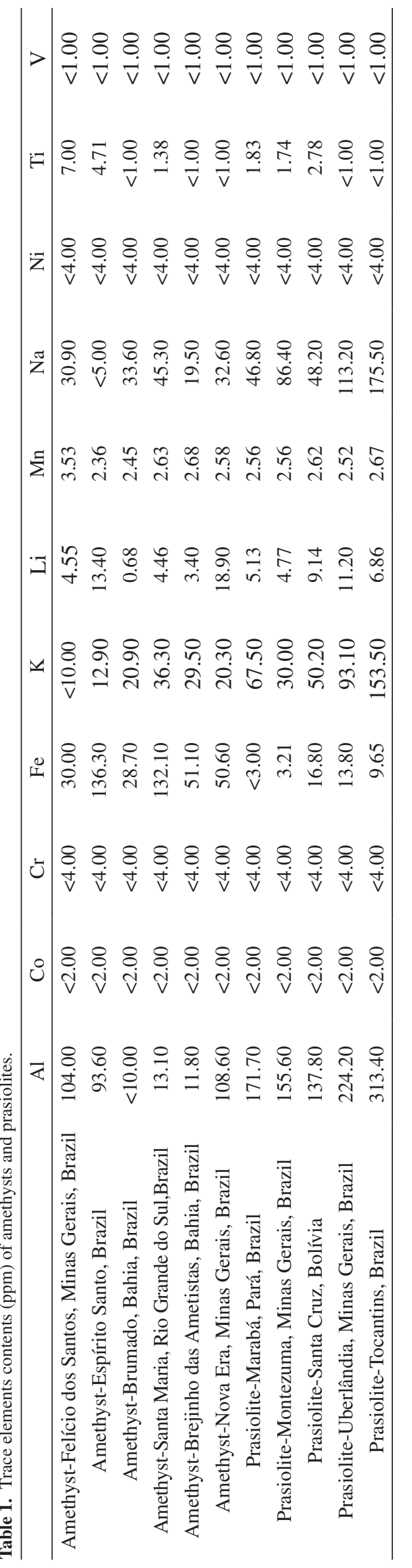

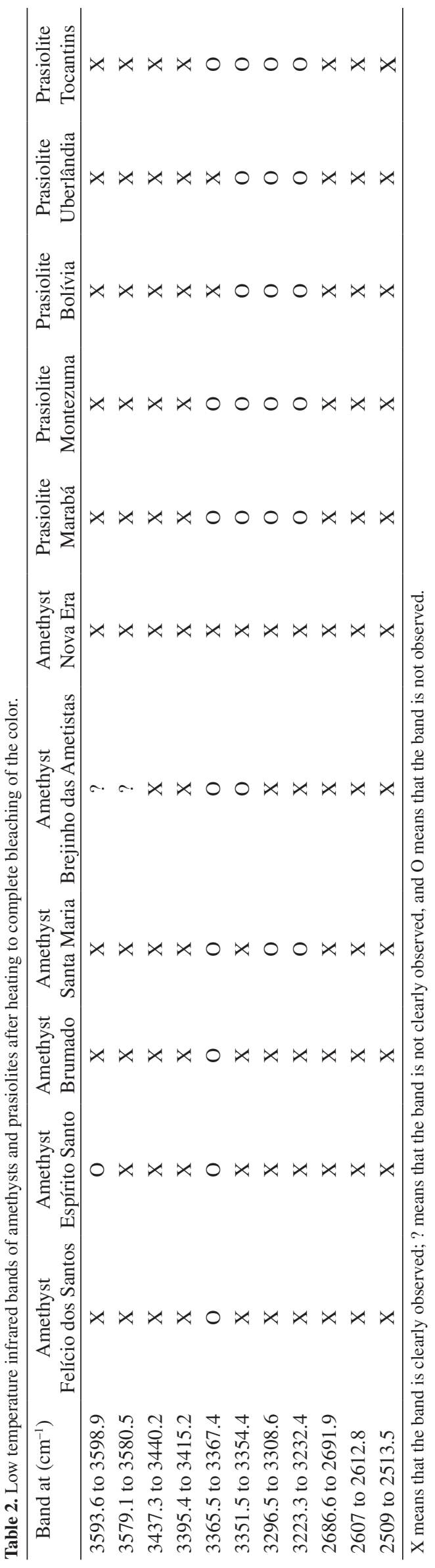


emission spectrometry using a Perkin Elmer spectrometer model ICP Optima 3000. The samples were sonicated in distilled and deionized water for surface cleaning. After drying in air, the samples were heated to $973 \mathrm{~K}$ and quenched in cold water to promote their fracture to help the grinding. This step is also important to crackle the fluid inclusions and to promote their leaching to the aqueous medium ${ }^{19}$. The grinding to a fine granulometry was performed in a mortar with a pestle, both made of high purity quartz. The powder was sonicated in distilled and deionized water and filtered in a Büchner vacuum funnel. The solubilization was performed in a polytetrafluoroethylene beaker with fluoridric, chloridric, and perchloric acids. The solution was dried at $373 \mathrm{~K}$. This procedure was repeated three times. Then sulfuric and chloridric acids were added and dried at $373 \mathrm{~K}$. The residue in the beaker was transferred to a volumetric flask with chloridric acid and distilled and deionized water. The trace contents were measured in two samples to verify the possibility of contamination and errors in the procedure above described. The trace contents were calculated according to $\mathrm{Guzzo}^{20}$. Fractions of the samples were ground and analyzed by X-ray powder diffraction to assure that all samples were quartz crystals. The diffractograms were taken using a Philips ${ }^{\circledR}$-PANalytical model PW-1710 (scan speed of 0,060 degrees per second).

Thin sheets about $1 \times 1 \mathrm{~cm}$ and $1 \mathrm{~mm}$ thickness were cut from the samples with a low speed rim diamond wafering blade, with the $\mathrm{c}$ axis perpendicular to the square faces. The sheets were ground and polished on both sides up to the diamond paste of $1 \mu \mathrm{m}$. They were heated in air up to $723 \mathrm{~K}$ until the complete bleaching of the colors.

The irradiation of the colorless sheets was performed in a Cobalt $^{\circledR}$-60 Nordion GB-127 panoramic dry gamma irradiator up to a dosis of $600 \mathrm{kGy}$. The temperature in the irradiation room was about $300 \mathrm{~K}$. The dose rate was not controlled, but it varied from 0.5 to $20 \mathrm{kGy} /$ hour.

Infrared absorption spectra of the sheets were measured using an ABB Bomem spectrometer model MB 102 (spectral range from 400 to $4000 \mathrm{~cm}^{-1}, 128 \mathrm{scans}$, and a resolution of $1 \mathrm{~cm}^{-1}$ ). Both room and low temperature spectra were measured. Since the bands are higher and thinner in the low temperature spectrum ${ }^{21}$, the observation of details not visible at room temperature is possible at low temperature. The low temperature measurements were performed with the same spectrometer and a variable temperature cell (88 to $298 \mathrm{~K}$ ) from Specac with $\mathrm{NaCl}$ windows and liquid nitrogen under low pressure (about 1.3 Pa).

Infrared spectra of samples of colorless quartz that become black after irradiation and greenish yellow to brown after heating or grayish olive green after irradiation and olive green after heating were also measured.

\section{Results and Discussion}

The X-ray diffraction revealed that all samples were high purity alpha quartz (content higher than 98\%).

Table 1 shows the trace contents in the samples. The main trace elements are, as expected, aluminum, iron, lithium, sodium, and potas$\operatorname{sium}^{7-14,22}$. The hydrogen content could not be measured. Amethysts have higher contents of iron (>20 ppm) and lower contents of sodium plus potassium, whereas prasiolites have higher contents of aluminum (>120 ppm) and sodium plus potassium.

A background of infrared absorption that rises, falls, or is constant for wavenumbers above $3000 \mathrm{~cm}^{-1}$ was observed. It was attributed to internal turbidity of the samples for the rising background $^{22}$ or to micro inclusions. Many samples show a noise between 3600 and $4000 \mathrm{~cm}^{-1}$ that was also attributed to micro inclusions. The Table 2 shows the bands observed in the infrared spectrum at low temperature. The position of these bands may vary within $10-20 \mathrm{~cm}^{-1}$. The last three bands are present in all samples of quartz. They were used to normalize the spectra by considering the absorption in one of them equal to 1 (the band at around $2690 \mathrm{~cm}^{-1}$ was chosen). A third order polynomial was fitted to the baseline in the range of 4100 to $5300 \mathrm{~cm}^{-1}$, where no bands are observed, and subtracted
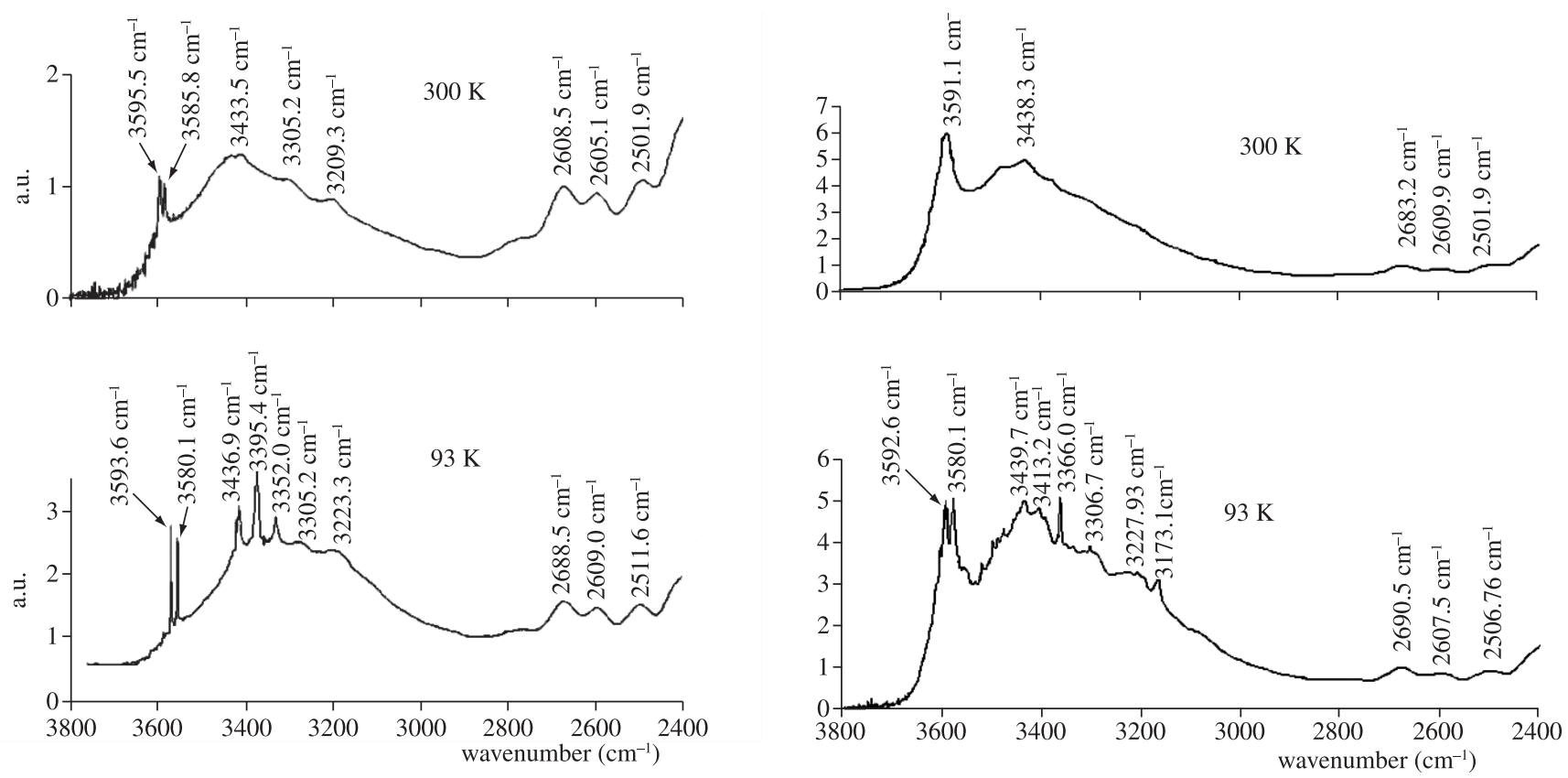

Figure 1. Infrared spectra at 300 and $93 \mathrm{~K}$ of the amethyst from Brumado, Bahia, Brazil after heating to colorless state.

Figure 2. Infrared spectra at 300 and $93 \mathrm{~K}$ of the amethyst from Uberlândia, Minas Gerais, Brazil after heating to colorless state. 
from the normalized spectra. The spectra presented in the following were obtained according to this procedure.

Figures 1 and 2 show typical infrared spectra of the samples measured at room and at low temperature. The prasiolites show a stronger absorption between 3200 to $3600 \mathrm{~cm}^{-1}$. At low temperature the bands in this range appear decomposed in different bands.

Only the amethyst sample from Espírito Santo didn't show the band at 3593.6 to $3598.9 \mathrm{~cm}^{-1}$. This sample has the lowest sodium and potassium content. The band at 3437.3 to $3440.2 \mathrm{~cm}^{-1}$ is attributed to $\mathrm{Al}_{\mathrm{Si}}-\mathrm{OH} / \mathrm{Na}$, and the bands at 3365.5 to $3367.4 \mathrm{~cm}^{-1}$ and 3296.5 to $3308.6 \mathrm{~cm}^{-1}$ are attributed to $\mathrm{Al}_{\mathrm{Si}}-\mathrm{OH}$. The bands at 3579.1 to $3580.5 \mathrm{~cm}^{-1}, 3395.4$ to $3415.2 \mathrm{~cm}^{-1}$, and 3351.5 to $3354.4 \mathrm{~cm}^{-1}$ are probably related to iron. The band at 3593.6 to $3598.9 \mathrm{~cm}^{-1}$ may also be observed in samples of colorless quartz that become smoky or black after irradiation and greenish yellow to brown after heating (Figure 3). The bands related to $\mathrm{Al}_{\mathrm{Si}}-\mathrm{OH} / \mathrm{Li}, \mathrm{Al}_{\mathrm{Si}}-\mathrm{OH} / \mathrm{Na}$, or $\mathrm{Al}_{\mathrm{Si}}-\mathrm{OH}$ are observed in these samples, but the bands attributed to iron are not observed. This band is probably related to $\mathrm{Al}_{\mathrm{Si}}-\mathrm{OH} / \mathrm{K}$ or $\mathrm{Al}_{\mathrm{Si}}-\mathrm{OH} / \mathrm{Na}$. It is apparently not correlated to the development of colors after irradiation. Karampelas at al. ${ }^{23}$ proposed that this band can be used to help the distinguishing of natural from synthetic amethyst, because it is present in most natural but absent in most synthetic amethyst, but they didn't discuss its nature.

Figure 4 shows the infrared spectra before and after irradiation. One observes a decrease of the absorption between 3200 and $3600 \mathrm{~cm}^{-1}$, which is probably related to the dissociation of $\mathrm{Al}_{\mathrm{Si}}-\mathrm{OH}$ and $\mathrm{Fe}_{\mathrm{Si}}-\mathrm{OH}$ centers. The amethysts recovered their original colors and the prasiolites become smoky green after irradiation. The smoky color of the prasiolites can be bleached by short exposition to ultraviolet rays, so that the original color can be obtained.

Smoky quartz is explained by the interaction of $\left[\mathrm{Al}_{\mathrm{Si}} \mathrm{O}_{4} / \mathrm{M}^{+}\right]^{0}$ centers with the radiation $\left(\mathrm{M}^{+}\right.$is the charge compensator, $\mathrm{H}^{+}, \mathrm{Li}^{+}$, or $\mathrm{Na}^{+}$). These centers are dissociated according to

$$
\left[\mathrm{Al}_{\mathrm{Si}} \mathrm{O}_{4} / \mathrm{M}^{+}\right]^{0} \rightarrow\left[\mathrm{Al}_{\mathrm{Si}} \mathrm{O}_{4} / \mathrm{h}^{+}\right]^{0}+\mathrm{M}^{+}+\mathrm{e}
$$

where $\mathrm{h}^{+}$is an electron hole ${ }^{24}$. The $\left[\mathrm{Al}_{\mathrm{Si}} \mathrm{O}_{4} / \mathrm{h}^{+}\right] 0$ center is responsible for the formation of the smoky quartz. After the dissociation of the $\left[\mathrm{Al}_{\mathrm{Si}} \mathrm{O}_{4} / \mathrm{M}^{+}\right]^{0}$ the $\mathrm{M}^{+}$is free to diffuse in the crystal lattice of quartz. The bands related to $\left[\mathrm{Al}_{\mathrm{Si}} \mathrm{O}_{4} / \mathrm{H}^{+}\right]^{0}$ show a small decrease after irradiation, because the $\mathrm{H}^{+}$has a high mobility in the quartz lattice. It may diffuse away very fast from the $\left[\mathrm{Al}_{\mathrm{Si}} \mathrm{O}_{4} / \mathrm{h}^{+}\right]^{0}$ center, but may also meet another $\left[\mathrm{Al}_{\mathrm{Si}} \mathrm{O}_{4} / \mathrm{h}^{+}\right]^{0}$ center so that the $\left[\mathrm{Al}_{\mathrm{Si}} \mathrm{O}_{4} / \mathrm{H}^{+}\right]^{0}$ is formed again with a high frequency. The bands related to $\left[\mathrm{Al}_{\mathrm{Si}} \mathrm{O}_{4} / \mathrm{Na}^{+}\right]^{0}$ also show a small decrease after irradiation, because the $\mathrm{Na}^{+}$has a low mobility in the quartz lattice. It remains near the $\left[\mathrm{Al}_{\mathrm{Si}} \mathrm{O}_{4} / \mathrm{h}^{+}\right]^{0}$ center so that the $\left[\mathrm{Al}_{\mathrm{Si}} \mathrm{O}_{4} / \mathrm{Na}^{+}\right]^{0}$ is formed again with a high frequency. Only the band related to $\left[\mathrm{Al}_{\mathrm{Si}_{\mathrm{i}}} \mathrm{O}_{4} / \mathrm{Li}^{+}\right]^{0}$ decreases after irradiation, because lithium has a moderate mobility in the quartz lattice. It may diffuse to an intermediate distance from the $\left[\mathrm{Al}_{\mathrm{Si}} \mathrm{O}_{4} / \mathrm{h}^{+}\right]^{0}$ center, so that the formation of $\left[\mathrm{Al}_{\mathrm{Si}} \mathrm{O}_{4} / \mathrm{Li}^{+}\right]^{0}$ is a less probable event. The same processes should work in the case of iron as a substitute for silicon in the quartz lattice, so that the reaction

$$
\left[\mathrm{Fe}_{\mathrm{Si}} \mathrm{O}_{4} / \mathrm{M}^{+}\right]^{0} \rightarrow\left[\mathrm{Fe}_{\mathrm{Si}_{\mathrm{i}}} \mathrm{O}_{4} / \mathrm{h}^{+}\right]^{0}+\mathrm{M}^{+}+\mathrm{e}
$$

should also takes place under irradiation. Potassium can also work as a charge compensator with a very low mobility due to its large ionic radius. Considering that the band related to $\left[\mathrm{Al}_{\mathrm{Si}} \mathrm{O}_{4} / \mathrm{Li}^{+}\right]^{0}$ was not observed in the samples, it is expected that the absorption in the infrared spectra should show, as observed, a nearly uniform decrease after irradiation, due to the formation of $\left[\mathrm{Al}_{\mathrm{Si}} \mathrm{O}_{4} / \mathrm{h}^{+}\right]^{0}$ and $\left[\mathrm{Fe}^{\mathrm{Si}} \mathrm{O}_{4} / \mathrm{h}^{+}\right]^{0}$ centers. The $\left[\mathrm{Fe}_{\mathrm{Si}_{\mathrm{i}}} \mathrm{O}_{4} / \mathrm{h}^{+}\right]^{0}$ is probably responsible for the formation of the violet color in amethyst and a high concentration of $\left[\mathrm{Al}_{\mathrm{Si}} \mathrm{O}_{4} / \mathrm{h}^{+}\right]^{0}$

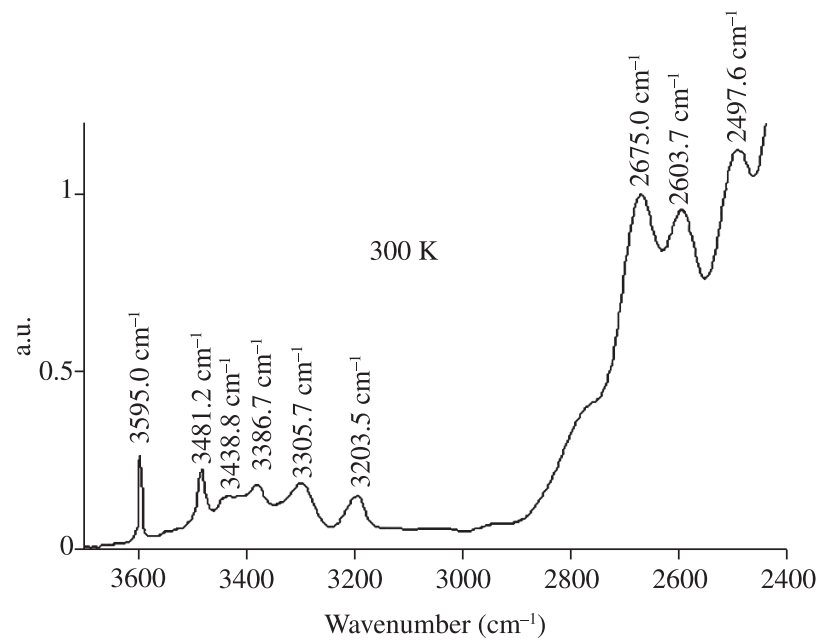

Figure 3 . Infrared spectrum at $300 \mathrm{~K}$ of a colorless sample of quartz from São José da Safira, Minas Gerais, Brazil that becomes smoky or black after irradiation and greenish yellow to brown after heating.

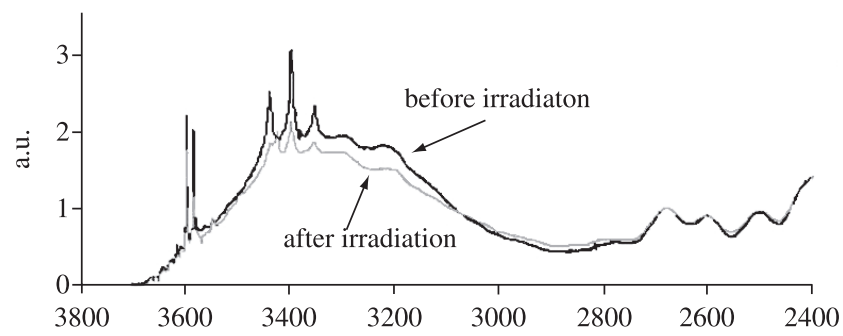

(a)

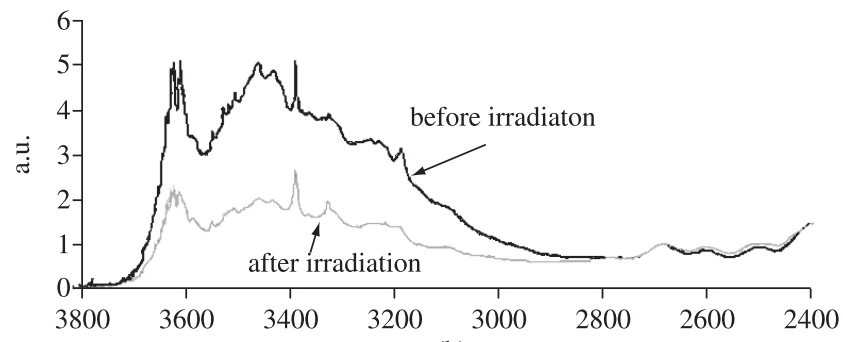

(b)

Figure 4. Infrared spectra at $93 \mathrm{~K}$ of a) amethyst from Brumado, Bahia, Brazil and b) prasiolite from Uberlândia, Minas Gerais, Brazil before and after irradiation with gamma rays up to $600 \mathrm{KGy}$.

should play a role in the formation of the green color of prasiolite. Lattice distortions may also contribute for the formation of color. They are expected if an iron atom replaces a silicon one. The ionic radius of the iron is large enough to cause distortions in the tetrahedral configuration of the quartz lattice. The iron also has an electronic configuration very different from the one of silicon. Its outer electrons are $3 d^{6} 4 s^{2}$, whereas the aluminum outer electrons are $3 s^{2} 2 p^{1}$, like the silicon ones, $3 \mathrm{~s}^{2} 2 \mathrm{p}^{2}$. This difference causes additional distortions in the lattice in the vicinity of an iron atom, because the tetrahedral configuration causes crystal field splitting of the 3d-orbitals of iron into two groups, with a lower energy splitting difference, which accounts for absorption of light by the $\left[\mathrm{Fe}_{\mathrm{Si}} \mathrm{O}_{4} / \mathrm{h}^{+}\right]^{0}$ center in longer wavelengths in comparison to the $\left[\mathrm{Al}_{\mathrm{Si}} \mathrm{O}_{4} / \mathrm{h}^{+}\right]^{0}$ center. The large ionic radius of potassium should also cause lattice distortions. The result 


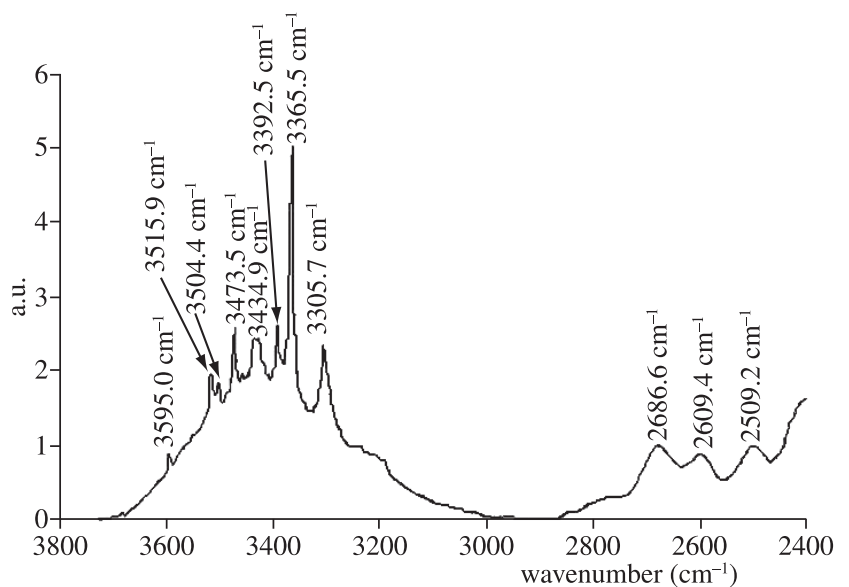

Figure 5. Infrared spectrum at $93 \mathrm{~K}$ of a sample of quartz from Marabá, Pará, Brazil that become smoky olive green after irradiation and olive green after heating.

Table 3. Bands observed in the infrared spectrum of natural quartz.

\begin{tabular}{clc}
\hline \multicolumn{1}{c}{ Band $\left(\mathrm{cm}^{-1}\right)$} & \multicolumn{1}{c}{ Relation to } & References \\
\hline 3593.6 to 3598.9 & $\mathrm{Al}(\mathrm{Al}-\mathrm{OH} / \mathrm{Na}$ ?, $\mathrm{Al}-\mathrm{OH} / \mathrm{K}$ ?) & - \\
3579.1 to 3580.5 & $\mathrm{Fe}(\mathrm{Fe}-\mathrm{OH} / \mathrm{Na}$ ?, Fe-OH/K ?) & - \\
3504 and 3515.9 & $\mathrm{Fe}(\mathrm{Fe}-\mathrm{OH} / \mathrm{Li} ?)$ & - \\
3473.5 to 3481.0 & $\mathrm{Al}-\mathrm{OH} / \mathrm{Li}$ & $8,11,17$ \\
3437.3 to 3440.2 & $\mathrm{Al}-\mathrm{OH} / \mathrm{Na}$ & \\
3395.4 to 3415.2 & $\mathrm{Fe}(\mathrm{Fe}-\mathrm{OH}$ ?, Fe-OH/Na ?) & \\
3365.5 to 3367.4 & $\mathrm{Al}-\mathrm{OH}$ & \\
3351.5 to 3354.4 & $\mathrm{Fe}(\mathrm{Fe}-\mathrm{OH} ?)$ & $8,11,17$ \\
3296.5 to 3308.6 & $\mathrm{Si}-\mathrm{O}, \mathrm{Al}-\mathrm{OH}$ & \\
\hline
\end{tabular}

is an overall shift of light absorption to longer wavelengths, which result in the violet or green colors instead of a smoky color.

There are samples of quartz that become smoky olive green after irradiation and olive green after heating. These samples have the spectrum shown in Figure 5. One notices a band at $3392.5 \mathrm{~cm}^{-1}$ (attributed to iron), a band at $3473.5 \mathrm{~cm}^{-1}$ (attributed to Al-OH/Li), and bands at 3504 and $3515.9 \mathrm{~cm}^{-1}$. The bands at $3595 \mathrm{~cm}^{-1}$ is observed, but the band at 3579.1 to $3580.5 \mathrm{~cm}^{-1}$ is not observed. The band at 3395.4 to $3415.2 \mathrm{~cm}^{-1}$ is observed in the amethysts and prasiolies, but the bands at $3473.5,3504$ and $3515.9 \mathrm{~cm}^{-1}$ are not observed. The bands at 3504 and $3515.9 \mathrm{~cm}^{-1}$, like the band at $3473.5 \mathrm{~cm}^{-1}$ (related to $\mathrm{Al}-\mathrm{OH} / \mathrm{Li}$ ), decrease after irradiation, probably because they are related to $\mathrm{Fe}-\mathrm{OH} / \mathrm{Li}$. The band at $3392.5 \mathrm{~cm}^{-1}$ may be related to $\mathrm{Fe}-\mathrm{OH}$ or Fe-OH/Na. Due to these characteristics of both the amethyst and the greenish yellow to brown quartz, we name this kind of quartz "heminefite", from the greek "hemo" (half) and "nepho" (sober), that means "the stone of the one that is half sober". Amethyst in ancient greek means "the stone of the one that is sober". Table 3 summarizes the relations of the infrared bands.

\section{Conclusions}

The amethyst samples have a content of iron greater than $20 \mathrm{ppm}$ and low contents of sodium and potassium. The prasiolites samples have a content of aluminum greater than $120 \mathrm{ppm}$ and a high contents sodium and potassium. The overall content of trace elements is higher in the prasiolite samples.
Colorless samples of natural quartz that become amethyst and prasiolite after irradiation have infrared spectra at room temperature with a broad band at around $3441 \mathrm{~cm}^{-1}$ and a band at $3585 \mathrm{~cm}^{-1}$. The samples that become prasiolites show a strong absorption between 3200 and $3600 \mathrm{~cm}^{-1}$, which may be related to their higher content of trace elements. The broad band at around $3441 \mathrm{~cm}^{-1}$ appears decomposed in several bands at low temperature. Some of them are bands related to $\mathrm{Al}-\mathrm{OH} / \mathrm{Na}\left(3437.3\right.$ to $3440.2 \mathrm{~cm}^{-1}$ ) and Al-OH (3365.5 to $3367.4 \mathrm{~cm}^{-1}$ ) reported in the literature. The band at 3593.6 to $3598.9 \mathrm{~cm}^{-1}$ is usually observed in samples that show only bands related to $\mathrm{Al}-\mathrm{OH}, \mathrm{Al}-\mathrm{OH} / \mathrm{Li}$, and $\mathrm{Al}-\mathrm{OH} / \mathrm{Na}$. This band is also probably related to aluminum. The other bands respectively at 3395.4 to $3415.2 \mathrm{~cm}^{-1}$ and 3351.5 to $3354.4 \mathrm{~cm}^{-1}$ are probably related to iron.

The irradiation decreases the absorption between 3200 and $3600 \mathrm{~cm}^{-1}$ in a nearly uniform way. This is expected due to the absence of an $\mathrm{Al}-\mathrm{OH} / \mathrm{Li}$ band in the infrared spectrum of the colorless samples than become amethysts or prasiolite after irradiation.

Heminefites show bands related to $\mathrm{Al}-\mathrm{OH} / \mathrm{Li}, \mathrm{Al}-\mathrm{OH} / \mathrm{Na}$, and Al-OH together with bands at $3515.9,3504.4$, and $3392.5 \mathrm{~cm}^{-1}$. The bands at 3515.9 and $3504.4 \mathrm{~cm}^{-1}$ are not observed in the amethyst and prasiolite samples. They are probably related to $\mathrm{Fe}-\mathrm{OH} / \mathrm{Li}$, so that the band at $3392.5 \mathrm{~cm}^{-1}$ is probably related to $\mathrm{Fe}-\mathrm{OH}$ or $\mathrm{Fe}-\mathrm{OH} / \mathrm{Na}$.

The color of amethysts and prasiolites are the result of the formation of $\left[\mathrm{Al}_{\mathrm{Si}} \mathrm{O}_{4} / \mathrm{h}^{+}\right]^{0}$ and $\left[\mathrm{Fe}_{\mathrm{Si}} \mathrm{O}_{4} / \mathrm{h}^{+}\right]^{0}$ centers formed by the exposure to ionizing irradiation and the influence of lattice distortions caused by the iron as a substitute for silicon and a high content of trace elements of large ionic radius like potassium.

\section{Acknowledgements}

To CNPq (Project number 305811/2006-1) and FAPEMIG (Project number APQ-7097-5.07/07).

\section{References}

1. Nabl A. The coloring constituents of amethyst, citrine, and burnt amethyst. Sitzungberichte der Akademie der Wissenschaften Wien Math.-naturw. Cl. 1899; 108(2):48-57.

2. Lehmann G, Moore WJ. Color center in amethyst quartz. Science. 1966; 152(3725):1061-1062.

3. Lehmann G. Yellow color centers in natural and synthetic quartz. Zeitschrift für Physik B Condensed Matter. 1971; 13(4):297-306.

4. Cohen AJ, Makar LN. Models for color centers in smoky quartz. Physica Status Solidi (a). 1982; 73(2):593-596.

5. Partlow DP, Cohen AJ. Optical studies of biaxial Al-related color centers in smoky quartz. American Mineralogist. 1986; 71(3-4):589-598.

6. Gunnarsson CFGA. Distinguishing between natural and synthetic quartz. [Master thesis]. Luleå: Luleå University of Technology; 2008.

7. Bahadur H. Infrared characterization of natural and cultured quartz: the effect of electrodiffusion and irradiation. Journal of Applied Physics. 1989; 66(10):4973-4982.

8. Bahadur H. Hydroxyls defects and electrodiffusion (sweeping) in natural quartz crystals. Journal of Applied Physics. 1993; 73(11):7790-7797.

9. Bahadur H. Sweeping and irradiation effects on hydroxyls defects in crystalline natural quartz. IEEE Transactions on Ultrasonics, Ferroelectrics, and Frequency Control. 1994; 41(6):820-833.

10. Bahadur H. Sweeping investigations on as grown $\mathrm{Al}-\mathrm{Li}^{+}$and $\mathrm{Al}-\mathrm{OH}$ centers in natural crystalline quartz. IEEE Transactions on Ultrasonics, Ferroelectrics, and Frequency Control. 1995; 42(2):153-158.

11. Guzzo PL, Iwasaki F, Iwasaki H. Al-related centers in relation to $\gamma$-irradiation. Response in natural quartz. Physics and Chemistry of Minerals. 1997; 24(4):254-263. 
12. Bachheimer JP. An investigation into hydrogen stability in synthetic, natural and air-swept synthetic quartz in air temperatures up to $1100{ }^{\circ} \mathrm{C}$. Journal of Physics and Chemistry of Solids. 1998; 49(5):831-840.

13. Bahadur H. Radiation-induced modifications of point defects in quartz crystals and their application in radiation dosimetry. Radiation Measurements. 2003; 36(1-6):493-497.

14. Bahadur H. Radiation induced modification of impurity-related point defects in crystalline quartz: a review. Crystal Research and Technology. 2006; 41(7):631-635.

15. Dotto CT, Osotani S. Irradiation and heating effects in amethyst crystals from Brazil. Radiation Effects and Defects in Solids. 1991; 117(4):355-361.

16. Nunes EHM, Lameiras FS. The optical absorption of gamma irradiated and heat-treated natural quartz. Materials Research. 2005; 8(3):305-308.

17. Lameiras FS, Nunes EHM, Melo VAR, Liz OR. Identificação de quartzos incolores para joalheria. REM: Revista Escola de Minas. 2006; 59(1):129-133.

18. Martin JJ. Electrodiffusion (sweeping) of ions in quartz: a review. IEEE Transactions on Ultrasonics, Ferroelectrics, and Frequency Control. 1988; 135(3):288-296.
19. Pasquali MA, Iwasaki H, Suzuki CK. Metodologia aplicada à separação de diferentes estados de impureza no quartzo. In: IX Congresso Brasileiro de Engenharia e Ciência dos Materiais; Águas de São Pedro: CNEN/ SP-IPEN e UFSCAR; 1990. p. 652-655.

20. Guzzo PL. Caracterização de impurezas estruturais e de centros de defeitos relacionados ao $\mathrm{Al}$ e $\mathrm{OH}$ no quartzo natural. [Máster thesis]. Campinas: Universidade Estadual de Campinas; 1992.

21. Fitzgerald SA, Churchill HOH, Korngut PM, Simmons CB, Strangas YE. Low-temperature infrared spectroscopy of H-2 in crystalline C-60. Physical Review B. 2006; 73(15):155409-1 - 155409-7.

22. Hebert LB, Rossmann GR. Greenish quartz from the Thunder Bay amethyst mine panorama, Thunder Bay, Ontario, Canada. The Canadian Mineralogist. 2008; 46(1):61-74.

23. Karampelas S, Fritsch E, Zorba T, Paraskevopoulos KM, Sklavounos S. Distinguishing natural from synthetic amethyst: the presence and shape of the $3595 \mathrm{~cm}^{-1}$ peak. Mineralogy and Petrology. 2005; 85(1-2):45-52.

24. Itoh N, Stoneham D, Stoneham AM. Ionic and electronic processes in quartz: mechanisms of thermoluminescence and optically stimulated luminescence. Journal of Applied Physics. 2002; 92(9):5036-5044. 